\title{
Identification of 19-Nor-deoxycorticosterone in Normal Rat Serum by Enzyme Immunoassay and Gas Chromatography-Mass Spectrometry
}

\author{
Yoshiharu KOBAYASHI ${ }^{1}$, Toshio OGIHARA ${ }^{2}$, YAYOI YAMAMURA ${ }^{1}$, \\ Fukuko WATANABE1, Toshiko KIGUCHI ${ }^{3}$, ICHIYA NINOMIYA ${ }^{3}$ \\ AND YUICHI KUMAHARA2 \\ Clinical Chemistry Laboratory ${ }^{1}$ and Medicinal Chemistry Laboratory ${ }^{3}$ of \\ Kobe Women's College of Pharmacy, 4-19-1, Motoyamakita-machi, \\ Higashinada-ku, Kobe 658 \\ Department of Medicine and Geriatrics ${ }^{2}$, Osaka University Medical \\ School, 1-1-50, Fukushima, Fukushima-ku, Osaka 553
}

\begin{abstract}
s
Recent reports on the isolation and identification of 19-nor-deoxycorticosterone from the urine of rats with adrenal regeneration hypertension give rise to the possibility of a role of this steroid in the pathogenesis of low renin essential hypertension. The present study was undertaken to investigate the presence of 19-nor-deoxycorticosterone in normal rat serum both by a sensitive enzyme immunoassay and by gas chromatography-mass spectrometry (GC/MS).

19-Nor-deoxycorticosterone in rat serum was separated from other steroids prior to enzyme immunoassay by using high performance liquid chromatography (HPLC). The average concentration of 19-nor-deoxycorticosterone in normal rat serum was $137 \pm 62 \mathrm{ng} / \mathrm{dl}($ mean $\pm \mathrm{SD}, \mathrm{n}=32$ ). Pooled normal rat serum $(50 \mathrm{ml})$ was purified by HPLC and the purified sample was acetylated with acetic anhydride for GC/MS measurement. The retention time and $\mathrm{m} / \mathrm{z}$ ions $(358,285$, and 257$)$ on the resulting mass fragmentogram coincided in position with those of authentic 21-acetoxy-19-nor-deoxycorticosterone and acetylated normal rat serum extract.

The combined characteristics of HPLC elution, antigen-antibody reaction, GC retention and selected ion responses provided strongly evidence supporting the presence of 19-nor-deoxycorticosterone in normal rat serum.
\end{abstract}

Previously it was reported that authentic 19-nor-deoxycorticosterone (19-nor-DOC) was from 1.5 to 5 times more potent than the parent steroid, 11-deoxycorticosterone (DOC), according to a sodium retaining bioassay (Axelrad et al., 1954; Kagawa and Armen, 1954). However, the existence of 19-norDOC in mammals was not confirmed until

Received November 28, 1983 its recent discovery in the urine of adrenal regeneration hypertensive rats (Gomez-Sanchez et al., 1979) and also in the urine of normal man (Dale et al., 1981). Thereafter, much interest has been centered on the establishment of the physiological significance of 19-nor-DOC in adrenal regeneration hypertensive rat and in man.

Recent studies have revealed 19-nor-DOC to have a higher affinity for mineralocorticoid 
receptors (Funder et al., 1978). Moreover, it has been shown that this steroid caused hypertension and hypokalemia, and reduced renin activity in rat (Hall et al., 1979). These studies suggest that 19-nor-DOC may possibly play an important role in causing hypertension in adrenal regeneration hypertensive rat. In this respect, a reliable method for estimating the amount of this steroid in circulating body fluid is important.

Here we report a highly sensitive enzyme immunoassay (EIA) of 19-nor-DOC and its application to the measurement of the steroid in normal rat serum. We also demonstrate the presence of 19-nor-DOC in normal rat serum by gas chromatographymass spectrometry (GC/MS).

\section{Materials and Methods}

Calf intestinal alkaline phosphatase (E.C. 3.1.3.1) was purchased from Boehringer Mannheim Gmbh, West Germany. 1-Ethyl-3-(3-dimethylaminopropyl) carbodiimide (EDAC) was obtained from Nakarai Chemical Co. Ltd., Japan. A Sep-Pak ${ }^{\circledR}$ C18 cartridge column was obtained from Waters Associates, U.S.A. A Chemcosorb 7 ODS-H column for high performance liquid chromatography (HPLC) was obtained from Chemco Scientific Co. Ltd., Japan. 19Nor-DOC: homogeneous, colorless crystal, m.p. $134-136^{\circ} \mathrm{C}$ (from ether); i.r. $\lambda_{\max } 3500,1700$, and $1660 \mathrm{~cm}^{-1}\left(\mathrm{CHCl}_{3}\right)$; u.v. $\lambda_{\max } 240 \mathrm{~nm}(\log$ 4.2) and 19-nor-DOC 3-(0-carboxymethyl) oxime were prepared according to methods by Sandoval et al. (1955) and Janoski et al. (1974). Antiserum to 19-nor-DOC 3-(0-carboxymethyl) oxime conjugated bovine serum albumin was raised in rabbit. The conjugation of alkaline phosphatase with 19-nor-DOC 3-(0-caboxymethyl) oxime was carried out by a method described elsewhere (Kobayashi et al., 1978). Steroid free serum was prepared according to a method described by Heyns et al. (1967). Male Wister rats (SPF; body weight $260-270 \mathrm{~g}$ ) were used. The animals were housed in our laboratory for 14 days before use under a day-night lighting schedule with a 6 a.m. -6 p.m. light cycle and were allowed ad libitum access to food and water.
Blood samples were obtained from the abdominal aorta under light ether anesthesia and the sera were frozen at $-20^{\circ} \mathrm{C}$ until assay.

\section{Extraction and purification of 19-nor-DOC from rat serum for EIA}

19 -Nor-DOC in $100 \mu \mathrm{l}$ of rat serum was extracted twice with $1 \mathrm{ml}$ of dichloromethane. The organic layer was evaporated in vacuo and the residue was dissolved with $200 \mu 1$ of $70 \%$ methanol. 19-Nor-DOC in the solution was isolated from other steroids by a reversed phase HPLC equipped with Chemcosorb 7 ODS-H column $(4.5 \mathrm{~mm} \mathrm{ID} \times 15 \mathrm{~cm})$. The temperature of the column was maintained at $30^{\circ} \mathrm{C}$ with a column jacket (Model CH-1445, Systec Inc., U.S.A.). The mobile phase was methanol: water $=70: 30$ and the flow rate was $1 \mathrm{ml} / \mathrm{min}$. 19-Nor-DOC fraction eluted from the column (retention time: $5.6 \mathrm{~min}$ ) was collected in an assay tube and used as the 19-nor-DOC EIA sample following evaporation of the solvent.

\section{9-Nor-DOC EIA procedure}

Alkaline phosphatase conjugated 19-nor-DOC $(100 \mu 1)$ was added to the assay tube containing either extracted 19-nor-DOC sample or 19-norDOC standard. Anti-19-nor-DOC antiserum (500 $\mu$ l) was then added to the tube which was incubated at room temperature for $1 \mathrm{~h}$. Following the addition of $100 \mu \mathrm{l}$ of anti-rabbit IgG goat antiserum, the tube was allowed to stand at $4^{\circ} \mathrm{C}$ for $16 \mathrm{~h}$. The resulting antigen-antibody complexes were washed twice with $2 \mathrm{ml}$ of distilled water. Finally, the alkaline phosphatase activity of the washed pellet was measured by the modified Kind-King method (Hansen 1966).

\section{Sample preparation of rat serum for GC/MS measurement}

A sample of $50 \mathrm{ml}$ of pooled normal rat serum was extracted three times with $50 \mathrm{ml}$ of dichloromethane. The dichloromethane layer was evaporated in vacuo and the residue was dissolved in $1 \mathrm{ml}$ of $50 \%$ methanol. The solution was applied to a Sep-Pak ${ }^{\circledR}$ C18 cartridge column. The column was eluted with $50 \%$ methanol and $15 \mathrm{ml}$ of the first eluate was collected. The solvent was evaporated to dryness and the residue was redissolved in $200 \mu 1$ of $70 \%$ methanol. The specimen was then applied to HPLC under the same described above. After evaporating the solvent of the 19-nor-DOC fraction, the residue 
was treated with acetic anhydride at room temperature overnight. The dried residue of the acetylated product was used for GC/MS measurement.

\section{Results and Discussion}

The specificity of the antiserum used was estimated from $50 \%$ cross reactivity of some other steroids using the present 19-nor-DOC EIA. The fifty percentage cross reactivity of DOC, 11-deoxycortisol, progesterone, corticosterone, 11-dehydrocorticosterone, and cortisol was $6.5,4.0,1.4,0.17,0.17$, and $0.001 \%$, respectively. From the results of the specificity study, 19-nor-DOC in rat serum was separated from other steroids prior to EIA, using the HPLC shown in Fig. 1. The calibration curve for 19-norDOC EIA is shown in Fig. 2. The minimal amount of 19-nor-DOC detected was $4 \mathrm{pg} /$ assay tube. Total recovery of 19-nor-DOC in serum was estimated from the proposed assay by adding authentic 19-nor-DOC to normal rat serum. The average recovery was $97 \pm 7 \%$ (mean $\pm S D, n=6)$, which was used for the correcting the serum concentration of 19-nor-DOC. Two serum samples were diluted with 19-nor-DOC free serum and their 19-nor-DOC concentrations were determined by the present method. A straight line, passing through the zero point, was obtained between the dilution and 19-norDOC concentration for each sample. The intra-assay and inter-assay coefficients of variation were $10.4 \%(n=5)$ and $16.7 \%$ $(\mathrm{n}=6)$, respectively. 19-Nor-DOC in normal rat serum was estimated by the proposed EIA and the average concentration of this steroid was found to be $137 \pm 62 \mathrm{ng} / \mathrm{dl}$ (mean $\pm \mathrm{SD}, \mathrm{n}=32$ ).

Fig. 3 shows a mass fragmentogram of authentic 21-acetoxy-19-nor-DOC and the acetylated normal rat serum extract. Monitored $\mathrm{m} / \mathrm{z}$ ions were $358\left(\mathrm{M}^{+}\right), 285\left(\mathrm{M}^{+}-73\right)$, and $257\left(\mathrm{M}^{+}-101\right)$ which were characteristic

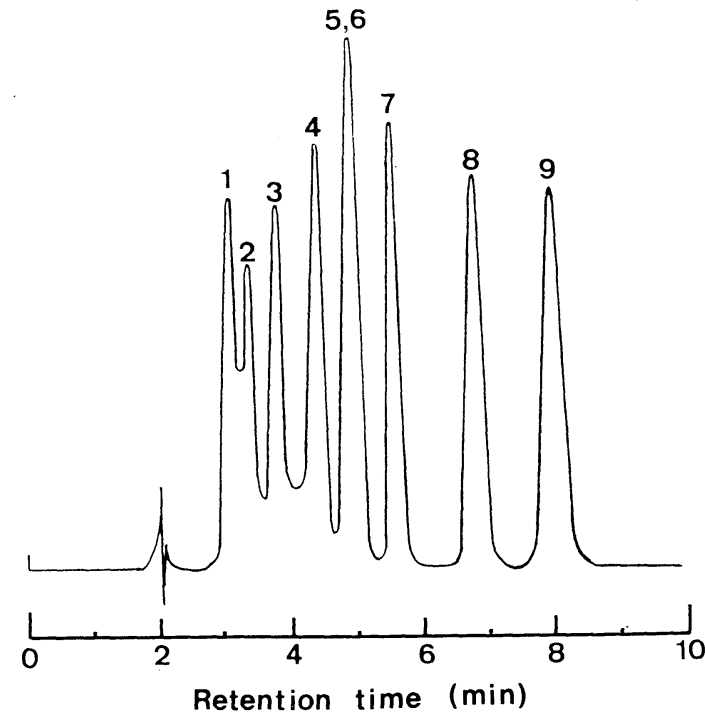

Fig. 1. Separation of authentic steroid mixtures by reversed phase HPLC: aldosterone (1), 18-hydroxycorticosterone (2), cortisol (3), 18hydroxy-11-deoxycorticosterone (4), 11-deoxycortisol (5), corticosterone (6), 19-nor-DOC (7), DOC (8), and 17 $\alpha$-hydroxyprogesterone (9). The HPLC conditions were as follows : Instrument: Waters Associates Inc. Model 6000 A pump, Model 440 absorbance detector. Column : Chemcosorb 7 ODS-H, $4.5 \mathrm{~mm}$ ID $\times 15 \mathrm{~cm}$. Column temperature: $30^{\circ} \mathrm{C}$. Solvent : methanol/water $=70 / 30$. Flow rate : 1 $\mathrm{ml} / \mathrm{min}$. Detector: UV $254 \mathrm{~nm}, 0.02$ absorbance unit of full scale.

of the structure in 21-acetoxy-19-nor-DOC. The retention time and $\mathrm{m} / \mathrm{z}$ ions on resulting mass fragmentogram coincided in position with those of authentic 21-acetoxy-19nor-DOC and acetylated normal rat serum extract. The combined characteristics of HPLC elution, antigen-antibody reaction, GC retention and selected ion responses provided strong evidence for the presence of 19-nor-DOC in normal rat serum.

Gomez-Sanchez et al. (1983) reported that on the 23rd day of adrenal regeneration, serum 19-nor-DOC could not be detected in either adrenal regeneration hypertensive or normal control rats which received $1 \%$ 


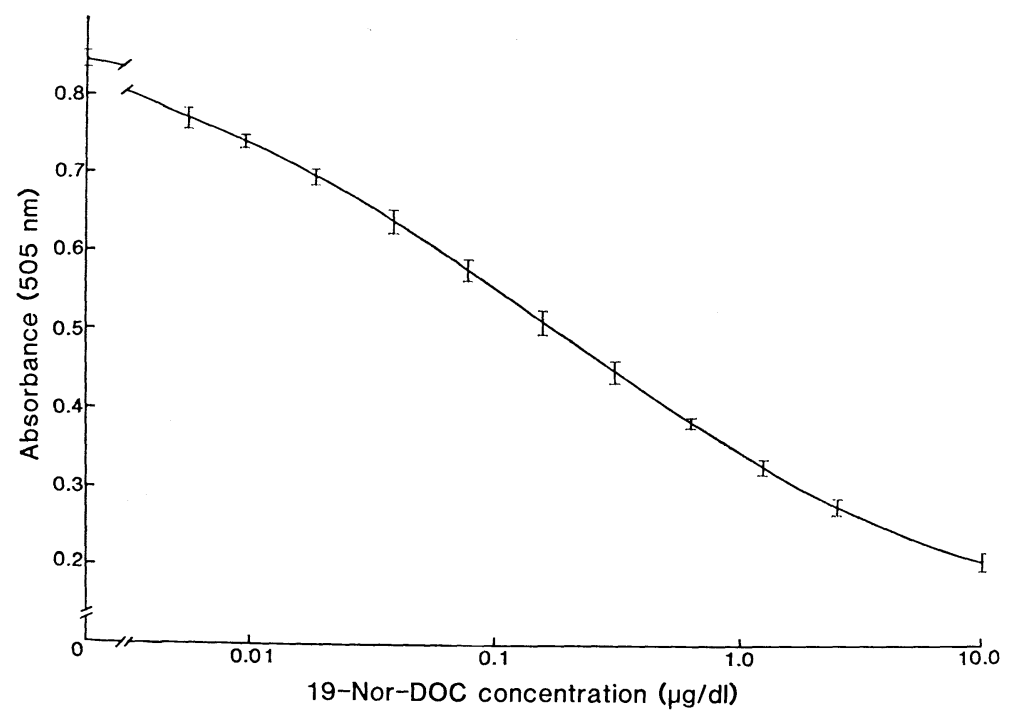

Fig. 2. Calibration curve for 19-nor-DOC EIA. The vertical bar indicates the standard deviation for six determinations.
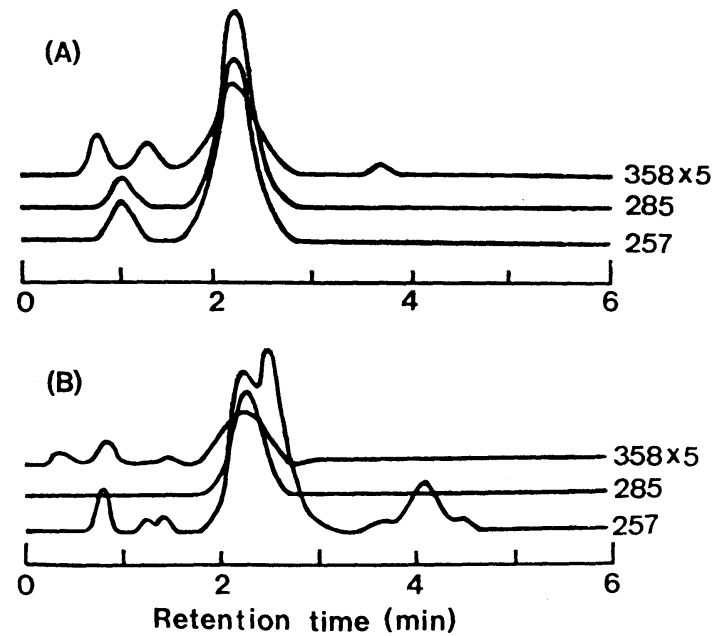

Fig. 3. Mass fragmentogram of authentic 21acetoxy-19-nor-DOC (A) and acetylated normal rat serum extract (B). GC/MS conditions were as follows: Instrument: Hitachi M-003 GC/MS spectrometer. Column: OV-101, 3 $\mathrm{mm} \mathrm{ID} \times 1 \mathrm{~m}$. Column temperature : $250 \rightarrow$ $300^{\circ} \mathrm{C}\left(4^{\circ} \mathrm{C} / \mathrm{min}\right)$. Herium gas flow rate: 45 $\mathrm{ml} / \mathrm{min}$. Accelerating voltage : $7 \mathrm{kV}$. Ionizing voltage : $20 \mathrm{eV}$. saline solution. From these results, they concluded that 19 -nor-DOC is not a circulating steroid hormone. However, according to our chronological observation of the serum 19-nor-DOC concentration in both groups, the 19-nor-DOC concentration was significantly different before and after the operation; the steroid concentration decreased 2-8 weeks after the operation (Saeki et al., 1983). This decrease in serum 19-nor-DOC may be caused by suppression of the reninangiotensin system by sodium loading. Dale et al. (1981) reported that the urinary levels of 19-nor-DOC rose following ACTH stimulation in man. These data suggest that 19nor-DOC may act as a steroidal hormone in the circulating body fluid. Although the exact mechanism for C-19 demethylation from the steroidal skeletal and metabolic pathway of this compound is not yet known, DOC and 19-hydroxy-11-deoxycorticosterone may possibly be precursors of 19-nor-DOC (Gomez-Sanchez et al., 1982; Dale et al., 1980).

In conclusion, we have developed EIA of 19-nor-DOC and used it for measuring the steroid concentration in normal rat 
serum. We also demonstrated the presence of the steroid in normal rat serum by $\mathrm{GC} /$ MS.

\section{Acknowledgements}

We wish to thank Dr. K. Saiki of the Kobe Women's College of Pharmacy for her valuable suggestions on GC/MS measurement. We also thank Dr. N. Akimori of Hitachi Ltd. for carrying out the GC/MS measurement. We are very grateful to Mr. Y. Sakata and Mr. M. Goto of Wako Pure Chemical Industry for immunization of 19-nor-DOC and to Dr. K. Ishibashi of Eiken Immunochemical Institute for kindly providing the anti-rabbit IgG goat antiserum. This work was supported in part by grants-in-aid for scientific research from the Japanese Ministry of Education, Science and Culture.

\section{References}

Axelrad, B. J., J. E. Cates, B. B. Johnson and J. A. Luetcher, Jr. (1954). Bioassay of mineralocorticoids. Relationship of structure to physiological activity. Endocrinol. 55, 568574.

Dale, S. L., M. M. Holbrook and J. C. Melby (1980). Identification of 19-hydroxydeoxycorticosterone in regenerating rat adrenal incubations. Steroids 36, 601-609.

Dale, S. L., M. M. Holbrook and J. C. Melby (1981). 19-Nor-deoxycorticosterone in the neutral fraction of human urine. Steroids 37, 103-109.

Funder, J. W., J. Mercer, B. Ingram, D. Feldman, K. Wynne and W.R. Adam (1978). 19Nor-deoxycorticosterone. Mineral corticoid receptor affinity higher than aldosterone, electrolyte activity lower. Endocrinol. 103, 15141517.

Gomez-Sanchez, C. E., O. B. Holland, B. A. Murray, H. A. Lloyd and L. Milewich (1979). 19-Nor-deoxycorticosterone......Potent mineral corticoid isolated from the urine of rats with regenerating adrenal. Endocrinol. 105, 708711.
Gomez-Sanchez, C.E., E. P. Gomez-Sanchez, C. H. L. Shackleton and L. Milewich (1982). Identification of 19-hydroxycorticosterone, 19oxo-deoxycorticosterone, and 19-oic-deoxycorticosterone as products of deoxycorticosterone metabolism by rat adrenals. Endocrinol. 110, 384-389.

Gomez-Sanchez, C. E., E.P. Gomez-Sanchez, R. J. Upcavage and E. B. Hall (1983). Urinary free and serum 19-nor-deoxycorticosterone in adrenal regeneration hypertension. Hypertension 5 (supp I), 32-34.

Hall, C.E., C.E. Gomez-Sanchez, O.B. Holland and D. Nasseth (1979). Influence of 19-nordeoxycorticosterone on blood pressure, saline consumption, and sodium electrolytes, corticosterone, and renin activity. Endocrinol. 105, 600-604.

Hauseu, P. W. (1966). A simplification of Kind and King's method for determination of serum phosphatase. Scandinav. J. Clin. \& Lab. Invest. 18, 353-356.

Heyns, W., H.V. Baelen and P.D. Moor (1967). Study of steroid-protein binding by means of competitive adsorption. Clin. Chim. Acta. 18, 361-370.

Janoski, A. H., F.C. Shulman and G.E. Wright (1974). Selective 3-(0-carboxymethyl) oxime formation in steroidal 3, 20-dione for hapten immunoassay. Steroids 23, 49-59.

Kagawa, C. M. and C. G. Van Armen (1957). Sodium retaining activity of 19 -nor-steroids in adrenalectomized rats. Proc. Soc. Exp. Biol. Med. 94, 444-447.

Kobayashi, Y., T. Ogihara, K. Amitani, F. Watanabe, T. Kiguchi, I. Ninomiya and Y. Kumahara (1978). Enzyme immunoassay for cortisol in serum using cortisol 21-amine. Steroids 32, 137-144.

Saeki, S., T. Ogihara, Y. Kumahara, Y. Kobayashi, Y. Yamamura and F. Watanabe (1983). Decreased serum 19-nor-deoxycorticosterone (21-hydroxy-19-nor-4-pregnene-3, 20-dione) level in adrenal regeneration hypertensive rats. Steroids 41, 99-104.

Sandoval, A., G. H. Thomas, C. Djerassi, G. Rosenkranz and F. Sondheimer (1955). Synthesis of 19-nor-deoxycorticosterone. A potent mineralocorticoid hormone. J. Am. Chem. Soc. 77, 148-151. 